\title{
Tijd voor een gewetensonderzoek
}

\author{
Gabriël van den Brink
}

Begin september verscheen Goed werk voor academici, een boek dat ik samen met Wout Scholten en Thijs Jansen schreef. Aanleiding was de onvrede die de afgelopen jaren aan de Nederlandse universiteiten ontstond en in meerdere protestacties tot uiting kwam. We wilden een beter zicht krijgen op de achtergronden van die onvrede en deden daartoe onderzoek naar de ervaringen van Nederlandse academici (Van den Brink, Scholten \& Jansen, 2016).

Het genoemde boek past in een reeks die we sinds tien jaar in samenwerking met de Stichting Beroepseer uitgeven. Maatgevend is een begrip dat we aan Amerikaanse onderzoekers hebben ontleend en dat 'Goed Werk' heet. Op basis daarvan hebben we ons veelvuldig verdiept in het werk van artsen, politieagenten, rechters, ambtenaren en leerkrachten. Om te kunnen spreken van 'Goed Werk' moet arbeid aan drie voorwaarden voldoen (Gardner, Csikszentmihalyi \& Damon, 2001). Ten eerste moet het in ambachtelijke zin beantwoorden aan hoge kwaliteitsnormen (excellence). Ten tweede moet het ruimte bieden voor persoonlijke ontplooiing en menselijke betrekkingen (engagement). Ten derde moet het passen bij waarden die in de samenleving breed worden gedeeld (ethics). Passen we deze criteria op de Nederlandse universiteiten toe, dan blijkt dat het huidige academische regime een drieledige bedreiging voor goed werk vormt. Ik schets dit eerst in algemene zin en spits de diagnose vervolgens op de sociale wetenschappen toe.

Hoewel excellentie voor sommigen inmiddels een besmette term is, blijft het streven naar een hoge ambachtelijke kwaliteit van het grootste belang. Het zijn uitsluitend de specialisten van een vakgebied die daarover kunnen oordelen. Ze doen dat door te kijken naar publicaties in gespecialiseerde tijdschriften. Gaandeweg is er een praktijk ontstaan dat men zich beperkt tot het tellen van artikelen. Bijgevolg worden academici in toenemende mate aan een cultuur van publish or perish onderworpen. Daarover is al veel te doen geweest. Hoewel iedereen weet dat je de kwaliteit van iemands werk uitsluitend kunt beoordelen als je de desbetreffende publicatie zelf leest, is tellen op Nederlandse universiteiten nog altijd gangbare praktijk. Vooral drukbezette bestuurders vinden het een makkelijk criterium en het speelt bij de aanstelling of bevordering van personeel dan ook een cruciale rol. Overigens tellen publicaties in andere talen dan het Engels zelden mee, terwijl het publiceren van boeken in tal van disciplines helemaal geen punten oplevert.

Een volgende bedreiging is dat het onderwijs onvoldoende aandacht krijgt. Medewerkers worden niet alleen afgerekend op hun artikelen, maar ook op de vraag hoeveel geld ze voor onderzoek werven. De waardering voor goed college geven of het begeleiden van studenten is veel minder hoog. Aan een ideaal als academische vorming komen de meeste instellingen niet toe. Zo wordt de publieke waarde van

* Prof. dr. Gabriël van den Brink is werkzaam bij Centrum Ethos, faculteit der Geesteswetenschappen, Filosofie van Cultuur en Bestuur, Vrije Universiteit Amsterdam. 
academisch werk enorm gereduceerd. Die reductie blijkt eveneens uit de manier waarop men wetenschap en samenleving op elkaar wil laten aansluiten. Daartoe werd vorig jaar een Nationale Wetenschapsagenda ingesteld. Op zich was dit een interessante stap die een onverwacht grote respons losmaakte. Vanuit de burgerij werden meer dan 11.000 vragen aan de wetenschap gesteld. Bij nadere analyse blijkt echter dat de gangbare wetenschapsbeoefening een grote invloed op die vragen heeft. Veel problemen worden vanuit een natuurwetenschappelijke, technologische en biomedische optiek bezien, terwijl culturele, geesteswetenschappelijke of normatieve perspectieven nauwelijks aan bod komen.

Een derde bedreiging is dat universiteiten de afgelopen jaren talloze regels en procedures hebben ingevoerd die een extra belasting vormen. Een voorbeeld daarvan zijn de vele visitaties die vaak kort op elkaar volgen. Een ander voorbeeld zijn afspraken die met de minister worden gemaakt en het vastleggen van prestaties vergen. Daardoor besteden medewerkers veel meer tijd aan bureaucratische verplichtingen dan bij hun aanstelling afgesproken was. In feite kan de Nederlandse wetenschap alleen maar draaien omdat het personeel vele overuren maakt. Bovendien begint zich een academisch proletariaat te vormen. Het zijn medewerkers die na de afronding van hun proefschrift een tijdelijk contract krijgen zonder uitzicht te hebben op een vaste baan. Omdat de doorstroommogelijkheden naar hogere functies beperkt zijn, treden ze als elkaars concurrenten op. Overigens blijken hun vooruitzichten ook niet best als ze uiteindelijk een baan buiten de universiteit zoeken, want dan rivaliseren ze met leeftijdsgenoten die een aantal jaren praktijkervaring hebben opgebouwd.

$\mathrm{Al}$ met al zijn er heel wat vraagtekens te plaatsen bij het regime waaronder Nederlandse wetenschappers werken. Ik zeg niet dat ze onder een dictatuur leven die het hen onmogelijk maakt om aan de drie eisen van goed werk te voldoen. Maar daarvoor betaal je wel een hoge prijs. Bijvoorbeeld in de vorm van lange werkweken, die een aanslag op je gezondheid of gezinsleven vormen. Als de huidige trends doorzetten, wordt het ontwikkelen van een kritische blik steeds moeilijker. Dat is niet goed voor de wetenschapsbeoefening, maar ook niet voor haar maatschappelijke betekenis en evenmin voor het zelfrespect van onze academici. Gegeven het tijdschrift dat de lezer voor zich heeft, spits ik deze diagnose toe op de sociale wetenschappen. Waar staan wij als het gaat om ambachtelijke kwaliteit, maatschappelijke relevantie en persoonlijke betrekkingen? Vooropgesteld dat elke generalisatie voor discussie vatbaar is, lijken mij drie zaken van belang.

\section{Excellentie}

Op het eerste oog brengen economen, psychologen, sociologen, politicologen en andere sociale wetenschappers betrouwbare kennis voort. Hun artikelen en proefschriften laten vaak kwantitatieve bevindingen, significante correlaties of getoetste hypothesen zien. Blijkbaar willen zij de exacte wetenschappen navolgen. Hoewel ik zelf een groot liefhebber ben van natuurwetenschappen, geloof ik niet dat menswetenschappers hun werkwijze kunnen toepassen. Het gedrag van mensen, groepen en samenlevingen is onvoorspelbaarder dan de dynamiek van het meest 
complexe molecuul. We mogen al blij zijn als we menselijke, sociale of maatschappelijke verschijnselen van een min of meer plausibele duiding kunnen voorzien. Maar we moeten wel proberen te begrijpen wat er in de samenleving gaande is en precies op dat punt schieten onze disciplines vaak hopeloos te kort. Een paar voorbeelden om te illustreren tot welke pijnlijke misrekeningen dit leidt.

Lange tijd stelden sociologen dat Nederland een multiculturele samenleving was. Sterker nog: velen meenden dat we het multiculturele samenleven als verrijking moesten omarmen en wie dat niet wilde, stond al snel te boek als een bekrompen geest. Totdat de twijfels toesloegen en de weerstand tegen het multiculturele denken steeds sterker werd. De kwestie is niet of deze tegenstanders gelijk hadden, het punt is dat de voorstanders van diversiteit de ommekeer niet zagen aankomen. Dat laatste geldt eveneens voor de economen die ons decennialang de zegeningen van het kapitalisme voorhielden. Het was nu eenmaal een superieur systeem en wie daaraan twijfelde, had niet goed begrepen waar het in de economie om gaat. Totdat in 2008 de crisis losbarstte en de economen hun mathematische modellen moesten loslaten. Een vergelijkbare dynamiek zagen we bij de Amerikaanse verkiezingen. Men geloofde dat het proces van globalisering per saldo heel voordelig was en niemand dacht dat verzet daartegen een serieuze kans van slagen had. Totdat Donald Trump de wereld op zijn kop zette. Ik denk niet dat academici tot taak hebben om dit soort ingrijpende gebeurtenissen te voorzien, maar het is veelzeggend dat ze keer op keer verrast worden. Het onderstreept nog eens dat de door hen ontwikkelde kennis minder betrouwbaar is dan ze graag doen voorkomen.

\section{Engagement}

Hoe kijken sociale wetenschappers tegen de tweede dimensie van goed werk aan? Over het algemeen zijn Nederlandse academici heel tevreden met hun baan, vooral omdat ze interessant onderzoek doen en beseffen dat het een voorrecht is om je eigen belangstelling te kunnen volgen. Wat niet wegneemt dat er grote verschillen tussen vakgebieden zijn en dat sommige disciplines relatief ongunstig afsteken. Dat komt vooral door de manier waarop het beoordelen en honoreren van werknemers in zijn werk gaat. Zoals gezegd kwam bij het verdelen van de (altijd schaarse) financiële middelen het onderzoek voorop te staan. Het geld ging men name naar onderzoeksprojecten die op afzienbare termijn een praktisch nut hebben. Dat speelt door in de manier waarop universiteiten hun medewerkers beoordelen. Uit onze studie blijkt dat gebieden als medische wetenschappen, natuurwetenschappen, landbouwwetenschappen en technische wetenschappen daarbij in het voordeel zijn, terwijl sociale wetenschappen, geesteswetenschappen, rechten en economie veeleer tekortkomen.

Critici hebben wel beweerd dat wetenschapsbeoefening op geen enkele wijze nuttig hoeft te zijn, maar dat lijkt ons niet van deze tijd. Je mag best vragen dat de wetenschap op een of andere manier haar nut bewijst, alleen moet je dan wel een onderscheid tussen nut op korte en nut op langere termijn maken. Bij technisch of medisch onderzoek is de praktische betekenis vaak duidelijk, bij sociaal- of 
menswetenschappelijk onderzoek veel minder vaak. Hun relevantie ligt er vooral in dat ze een nieuwe generatie intellectuelen opleiden waarvan de waarde pas veel later zichtbaar wordt. Het gevolg is dat ze minder tijd hebben voor onderzoek en een relatief groot deel van hun tijd aan onderwijs kwijt zijn. Helaas komt het geven van goed onderwijs aan Nederlandse universiteiten op de tweede plaats. Dat betekent voor academici in de mens- en maatschappijwetenschappen dat ze onvoldoende toekomen aan het doen van onderzoek, terwijl ze maar weinig waardering krijgen voor datgene wat hen de meeste uren kost. Het is dan ook geen wonder dat de onvrede die twee jaar geleden plotseling naar boven kwam, bij geesteswetenschappen en sociale wetenschappen het sterkst was.

\section{Ethiek}

Hoe staan de sociale wetenschapen ervoor waar het gaat om de publieke waarde van hun inzichten? Laten we erkennen dat maatschappelijke problemen niet allemaal oplosbaar zijn en dat de relevantie van sociale wetenschappen soms elders ligt. Bijvoorbeeld doordat ze laten zien hoe je vanuit diverse achtergronden tegen urgente vraagstukken kunt aankijken. Maar dan moet het wel om realiteiten gaan en niet om zelfverzonnen grootheden. Persoonlijk denk ik dat nogal wat academici een eigen realiteit scheppen die op grote afstand van het echte leven staat. Neem bijvoorbeeld de onderzoekers die zich de afgelopen decennia in genderstudies gespecialiseerd hebben. Ze menen dat de verschillen tussen man en vrouw een sociale constructie vormen en weinig met biologie van doen hebben. Terwijl iedereen die een langdurige relatie heeft of kinderen moet opvoeden beseft dat lichamelijke of gevoelsmatige verschillen naar geslacht een grote rol spelen en dat je vaak problemen krijgt als je er onvoldoende aandacht aan besteedt. Of neem degenen die lange tijd hebben gedacht dat religieuze praktijken min of meer vanzelf verdwijnen naarmate de moderne samenleving vormt krijgt. Dat is misschien het geval voor Nederland en omstreken, maar voor de meeste samenlevingen elders ter wereld gaat het omgekeerde op. Daar neemt het belang van religieuze praktijken of denkbeelden juist toe, en zelfs zozeer dat sommigen op religieuze gronden overgaan tot terreurdaden.

Als laatste voorbeeld noem ik het idee dat je problemen in de zorg en andere delen van de publieke sector met marktwerking kunt oplossen. Slimme wetenschappers betogen dat de zorg door een meer bedrijfsmatige werkwijze goedkoper, doelmatiger en veel beter wordt. Intussen zitten de meeste zorgprofessionals niet te wachten op marktwerking en dat gaat a fortiori voor de patiënten zelf op. Desondanks houden heel wat bestuurskundigen vast aan het idee dat meer marktwerking hét antwoord op allerlei problemen is. Binnen hun vakgebied hebben ze wellicht gelijk, maar wanneer men hun adviezen vanuit de maatschappelijke realiteit beziet, vraagt men zich onwillekeurig af waar ze mee bezig zijn. Dat moeten we bij eventuele klachten over een verminderd gezag van wetenschappers in het oog houden. Men kan wel zeggen dat de burgers vandaag de dag geen respect meer voor de feiten, voor argumenten en voor expertise aan de dag leggen, 
maar de vraag is ook hoe relevant die expertise is voor mensen die in hun leven met problemen worstelen.

Daarom ben ik van mening dat het tijd wordt voor een gewetensonderzoek. Opzienbarende gevallen van fraude (denk aan Stapel) leiden onze aandacht van de hoofdzaak af. Er is in de sociale wetenschappen nog heel wat te verbeteren voordat er sprake is van 'Goed Werk' voor academici. Daarbij gaat het niet alleen om de vraag welke onderwerpen we centraal stellen (publieke relevantie), maar ook om de aard van onze werkwijze of inzichten (ambachtelijke kwaliteit) én om de manier waarop we samenwerken (personeelsbeleid). Het spreekt voor zich dat externe factoren zoals schaarse middelen, prestatieafspraken of internationalisering daarbij een rol spelen. Maar we zouden als sociale wetenschappers ook bij onszelf te rade kunnen gaan.

\section{Literatuur}

Brink, G. van den, Scholten, W., \& Jansen, Th. (red.) (2016). Goed werk voor academici. Culemborg: Stichting Beroepseer.

Gardner, H., Csikszentmihalyi, M., \& Damon, W. (2001). Good Work. When Excellence and Ethics meet. New York: Basis Books. 